\title{
Elemental diet directly affects chemotherapy-induced dermatitis and raw wound areas
}

\author{
KOJI HARADA $^{1}$, TAKANORI TAKENAWA ${ }^{1}$, TARANNUM FERDOUS ${ }^{1}$, \\ YOICHI MIZUKAMI ${ }^{2}$ and KATSUAKI MISHIMA ${ }^{1}$ \\ ${ }^{1}$ Department of Oral and Maxillofacial Surgery, Yamaguchi University Graduate School of Medicine; \\ ${ }^{2}$ Center for Gene Research, Yamaguchi University, Ube, Yamaguchi 755-8505, Japan
}

Received November 9, 2019; Accepted February 21, 2020

DOI: $10.3892 / \mathrm{mco} .2020 .2050$

\begin{abstract}
Elental ${ }^{\circledR}$ is an L-glutamine-rich elemental diet (ED) that has been widely used in Japan as a nutritional supplement for malnourished patients. In addition, Elental ${ }^{\circledR}$ has been successfully used in the management of chemotherapy-induced mucositis in cancer patients. Recently, it was also reported that Elental ${ }^{\circledR}$ can effectively reduce chemotherapy-induced oral mucositis in patients with oral squamous cell carcinoma, and can also reduce mucositis and dermatitis in animal models. However, it is unclear whether oral intake or topical application of Elental ${ }^{\circledast}$ can act directly on chemotherapy-induced oral mucositis or dermatitis. The aim of the present study was to investigate the possible direct healing effect of Elental ${ }^{\circledR}$ on chemotherapy-induced dermatitis and raw wound areas in a mouse model. Dermatitis and raw wounds were induced in nude mice by administration of 5-fluorouracil (5-FU) (via gastric tube) and mechanical injury (using a metal brush or a surgical knife). We then compared the outcome following oral or topical application of Elental ${ }^{\circledR}$ in these mice. The effect of Elenta $l^{\circledR}$ on the growth and migration ability of the human oral keratinocyte cell line, HOK, was also examined using MTT and migration assays, respectively. In the mouse model, both oral administration and topical application of Elental ${ }^{\circledR}$ reduced 5-FU-induced dermatitis and healed raw wound areas more effectively compared with the topical application of saline. The MTT assay revealed that Elental ${ }^{\circledR}$ exerted a growth-promoting effect on HOKs. In addition, Elenta ${ }^{\circledR}$ enhanced the ability of HOKs to migrate, as demonstrated by the migration assay. These findings demonstrated that the topical application as well as the oral intake of Elental ${ }^{\circledR}$ exerted a direct healing effect on chemotherapy-induced dermatitis or raw wound areas. The
\end{abstract}

Correspondence to: Dr Koji Harada, Department of Oral and Maxillofacial Surgery, Yamaguchi University Graduate School of Medicine, 1-1-1 Minamikogushi, Ube, Yamaguchi 755-8505, Japan E-mail: harako@yamaguchi-u.ac.jp

Key words: elemental diet, dermatitis, raw wound area, oral mucositis, direct effect data also indicated that oral intake of an ED may exert a direct healing effect on chemotherapy-induced oral mucositis.

\section{Introduction}

Elental ${ }^{\circledR}$ is an elemental diet (ED) with a high L-glutamine content that has been used in Japan as a treatment for individuals who are malnourished, patients with cancer, and patients with inflammatory bowel disease (1-5). This diet has an easily digestible nutritional formula that combines 18 amino acids, carbohydrates, vitamins and minerals, with minimal fat content $(1,5)$. Elental ${ }^{\circledR}$ has been reported to be useful in the treatment of Crohn's disease, as it can suppress bowel inflammation and allow the bowel to rest (6-9). It has also been suggested that Elental ${ }^{\circledR}$ consumption may lower the incidence of chemotherapy-related hematological toxicity in patients with gastric cancer, and may decrease pancreatic pain in patients with chronic pancreatitis $(10,11)$. It was also reported that Elental ${ }^{\circledR}$ may be useful for the management of chemotherapy-induced mucositis in patients with various types of cancer (12-16). Miki et al reported that the amino acid components of Elental ${ }^{\circledR}$ increased the survival rate of rats with acute liver injury, by lowering the expression of nitric oxide synthase and tumor necrosis factor (TNF)- $\alpha$; it was also found to inhibit the expression of inflammatory mediators and nuclear factor (NF)- $\mathrm{\kappa B}$ activation in cultured hepatocytes in vitro (17).

Elental ${ }^{\circledR}$ has been used for the treatment of malnutrition in patients with oral squamous cell carcinoma (OSCC) in recent years, and our clinical studies have revealed its healing effects on oral mucositis and dermatitis in patients with OSCC who were receiving chemotherapy and radiotherapy $(18,19)$. Recently, it was also reported that Elenta ${ }^{\circledR}$ reduced chemotherapy-induced oral mucositis and dermatitis in hamster and mouse models $(20,21)$. In addition, our in vitro studies revealed that Elental ${ }^{\circledR}$ may accelerate the recovery from 5-fluorouracil (5-FU)-induced oral mucositis and dermatitis through the induction of fibroblast growth factor (20). Moreover, it was demonstrated that Elental ${ }^{\circledR}$ suppresses the expression of pro-inflammatory cytokines, such as TNF- $\alpha$, interleukin (IL)- $1 \beta$ and IL-6, in keratinocytes by inhibiting NF- $\mathrm{\kappa B}$ (21). However, the detailed mechanisms of its action in healing wounded regions, mucositis and dermatitis remain unclear. 
Interestingly, in our clinical studies it was observed that Elental ${ }^{\circledR}$ tends to reduce chemotherapy-induced oral mucositis more effectively by oral administration (OA) rather than by nasal administration. Therefore, it was hypothesized that Elenta ${ }^{\circledR}$ may affect chemotherapy-induced oral mucositis directly, as well as indirectly through gut immunity in the intestine/stomach. However, it remains unclear whether the oral intake of ED can act directly on chemotherapy-induced oral mucositis or dermatitis.

The aim of the present study was to investigate whether Elental ${ }^{\circledR}$ directly affects chemotherapy-induced and mechanically induced dermatitis or raw wound areas in a mouse model, and to elucidate the possible mechanism underlying the action of Elental ${ }^{\circledR}$ in the wound healing process. Therefore, the effects of Elental ${ }^{\circledR}$ on the growth and migration of healthy and 5-FU-treated keratinocytes were examined in vitro.

\section{Materials and methods}

Animals. A total of 24 female athymic nude mice, aged 4 weeks and weighing 20-25 g, with a CAnN.Cg-Foxnlnu/CrlCrlj genetic background, were purchased from CLEA Japan, Inc. The mice were housed in a pathogen-free, sterile and temperature-controlled environment under a $12 \mathrm{~h}$ light/dark cycle, and they were provided access to water and food ad libitum. All procedures including animal handling and the experimental protocols were conducted according to the guidelines approved by the Ethical Committee for Animal Experimentation of Yamaguchi University (Yamaguchi, Japan).

Induction of experimental dermatitis and raw wound areas. A total of 12 nude mice were used for the dermatitis model. Dermatitis was induced by two intraperitoneal (i.p.) administrations of $60 \mathrm{mg} / \mathrm{kg}$ 5-FU (Wako Pure Chemical Industries, Ltd.) on the first and third days of the experiment, together with superficial scratching of the dorsal skin with a metal brush under anesthesia (pentobarbital sodium, $30 \mathrm{mg} / \mathrm{kg}$, i.p.; Somnopentyl ${ }^{\circledR}$, Kyoritsu Seiyaku Co., Ltd.), until erythematous changes in the skin were observed (Fig. 1A), on the second and third days of the experiment. Similarly, raw wound areas were also induced in 12 nude mice by two i.p. administrations of $60 \mathrm{mg} / \mathrm{kg} 5-\mathrm{FU}$ on the first and third days of the experiment, followed by dermabrasion of the dorsal skin with a surgical knife (no. 15) under Somnopentyl ${ }^{\circledR}$ anesthesia on the second day of the experiment (Fig. 1B).

In vivo experimental groups. The experimental design of our in vivo study is outlined in Fig. 1. A total of 6 groups of nude mice were set up ( $\mathrm{n}=4$ /group), as described below, with dermatitis induced by 5 -FU + abrasion, or raw wound areas induced by $5-\mathrm{FU}+$ dermabrasion. Briefly, the $5-\mathrm{FU}+$ abrasion and the 5-FU + dermabrasion groups served as the untreated controls in this experiment, and they received only topical application of saline $(1 \mathrm{ml} /$ body/day) from the third day of the experiment onwards. Elental ${ }^{\circledR}$ was purchased from EA Pharma Co., Ltd. The OA group and the topical application (TA) group received Elental ${ }^{\otimes}(18 \mathrm{kcal} / 100 \mathrm{~g}$ body weight/day), which was administered daily, either orally or topically, from the third day of experiment onwards until the wounded area was almost completely healed. All mice were sacrificed using an overdose of Somnopentyl ${ }^{\circledR}$ (sodium pentobarbital, $200 \mathrm{mg} / \mathrm{kg}$; Merck \& Co., Inc.) at the end of the experiment. The healing of the dermatitis or raw areas of each mouse was assessed daily and the affected area was measured. The area of each lesion was calculated by multiplying the length $(\mathrm{mm}) \mathrm{x}$ width $(\mathrm{mm})$.

Cell lines and cell culture. The human oral keratinocyte cell line, HOK, was purchased from ScienCell Research Laboratories. The cells were cultured in Oral Keratinocyte Medium(OKM)-New Zealand Origin BPE medium(OKM-NZ; cat. no. 2611-NZ; ScienCell Research Laboratories) at $37^{\circ} \mathrm{C}$ in a humidified atmosphere containing $5 \% \mathrm{CO}_{2}$. OKM-NZ complete medium consists of OKM basal medium supplemented with $1 \%$ oral keratinocyte growth supplement-New Zealand Origin BPE (OKGS-NZ, cat. no. 2652NZ; ScienCell Research Laboratories) and $1 \%$ penicillin/streptomycin solution (cat. no. 0503; ScienCell Research Laboratories).

Cell proliferation assay. Cells $\left(5 \times 10^{3}\right.$ cells per well) were seeded on 96-well plates (Becton Dickinson Labware) in OKM-NZ complete medium. After $24 \mathrm{~h}$, the medium was exchanged for OKM-NZ medium containing 0 or $1 \%$ OKGS-NZ growth supplement, or OKM-NZ medium containing $1 \%$ OKGS-NZ and 5-FU (final concentration, $2 \mu \mathrm{g} / \mathrm{ml}$ ). After $24 \mathrm{~h}$, the cells were treated with different concentrations of Elental ${ }^{\circledR}(0,0.1$, $0.5,1,5,10,50$ or $100 \mu \mathrm{g} / \mathrm{ml}$ ) dissolved in OKM-NZ medium containing 0 or $1 \%$ OKGS-NZ growth supplement (Fig. 2). After a further $24 \mathrm{~h}$, MTT ( $25 \mu \mathrm{l} /$ well) was added to the 96-well plate and incubated for $4 \mathrm{~h}$ at $37^{\circ} \mathrm{C}$. Next, the culture medium was removed and replaced with dimethyl sulfoxide (100 $\mu \mathrm{l} /$ well), and the absorbance was measured with a spectrophotometer (BioRad Laboratories, Inc.) at $490 \mathrm{~nm}$. Each treatment group was examined for its cell proliferation ability. All assays were performed in triplicate.

Cell migration assay. The cell migration assay was performed using a Boyden chamber, according to the manufacturer's instructions (Neuro Probe). Briefly, $25 \mu 1$ OKM-NZ medium containing 0 or $1 \%$ OKGS-NZ growth supplement plus different concentrations of Elental ${ }^{\circledR}(0,0.1,0.5,1,5,10,50$ or $100 \mu \mathrm{g} / \mathrm{ml}$ ) was added as chemoattractant in the lower chamber. Next, $5 \times 10^{3}$ cells in $50 \mu \mathrm{l}$ OKM-NZ medium containing $0 \%$ OKGS-NZ were seeded on a gelatin-coated polycarbonate membrane in the upper chamber. After the cells had been incubated for $24 \mathrm{~h}$ at $37^{\circ} \mathrm{C}$, the polycarbonate membrane was washed three times at room temperature $(2 \mathrm{~min} / \mathrm{wash})$ with phosphate-buffered saline, and any cells on the top surface of the polycarbonate membrane were removed using a cotton swab. Cells adhering to the lower surface were fixed with methanol for $15 \mathrm{~min}$ at room temperature, stained with hematoxylin solution for $20 \mathrm{~min}$ at room temperature, and counted under an optical microscope (BX51; Olympus Corporation) in five predetermined fields (magnification, $\mathrm{x} 200$ ). All assays were independently repeated at least three times.

Statistical analysis. All data are expressed as means \pm standard deviation (SD). The significance of the experimental results was determined using one-way analysis of variance (ANOVA) and Tukey-Kramer multiple comparisons tests. The differences were considered to be statistically significant when $\mathrm{P}<0.05$. 
A

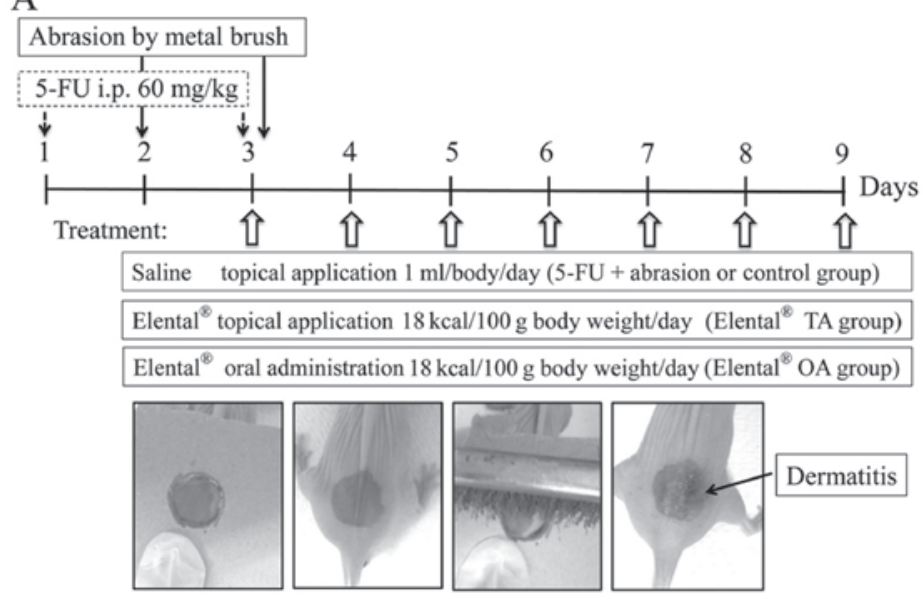

B
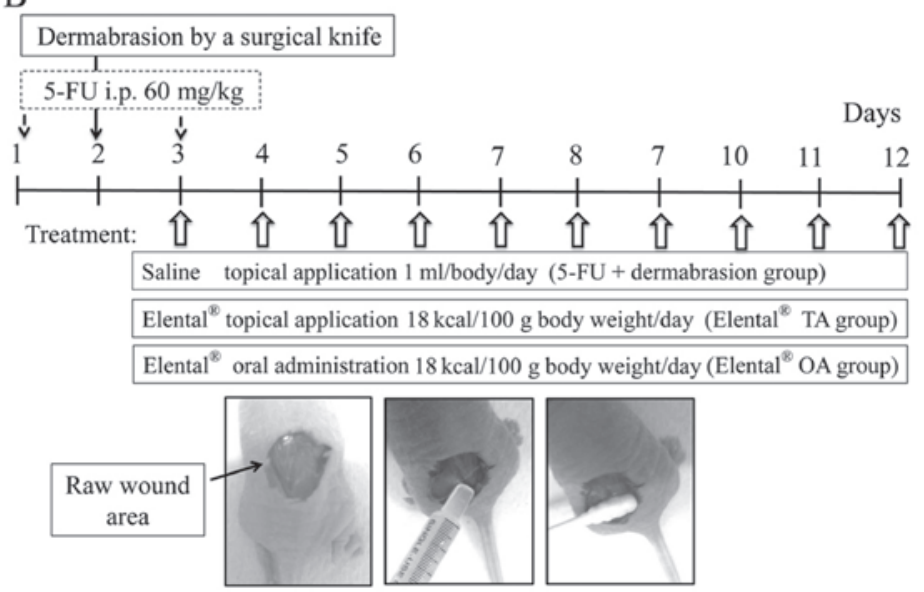

Figure 1. Induction of dermatitis or raw wound areas in a mouse model. (A) Dermatitis on nude mouse dorsal skin was induced by the intraperitoneal (i.p.) injection of 5-FU ( $60 \mathrm{mg} / \mathrm{kg}$, i.p.) on days 1 and 3, along with mechanical trauma on days 2 and 3 of the experiment. There were three experimental groups as follows: The 5-FU + abrasion group received saline only $(1 \mathrm{ml} /$ body/day; $\mathrm{n}=4)$; the Elental ${ }^{\circledR} \mathrm{TA}$ group received Elental ${ }^{\circledR}$ by TA $(18 \mathrm{kcal} / 100 \mathrm{~g} \mathrm{body} \mathrm{weight/day;}$ $\mathrm{n}=4)$; and the Elenta ${ }^{\circledR}$ OA group received Elental ${ }^{\circledR}$ by OA $(18 \mathrm{kcal} / 100 \mathrm{~g}$ body weight/day; $\mathrm{n}=4)$; all administrations were performed daily, starting from day 3 of the experiment until the mice were sacrificed. (B) Raw wound areas on nude mouse dorsal skin were induced by i.p. injection of $5-\mathrm{FU}$ ( $60 \mathrm{mg} / \mathrm{kg}$, i.p.) on days 1 and 3 of the experiment, followed by dermabrasion with a surgical knife on day 2 of the experiment. There were three experimental groups as follows: The 5-FU + dermabrasion group received saline only $(1 \mathrm{ml} /$ body/day; $\mathrm{n}=4)$; the Elental ${ }^{\circledast} \mathrm{TA}$ group received Elental ${ }^{\circledR}$ by TA $(18 \mathrm{kcal} / 100 \mathrm{~g} \mathrm{body} \mathrm{weight/day;}$ $\mathrm{n}=4)$, and the Elenta ${ }^{\circledR}$ OA group received Elental ${ }^{\circledR}$ by OA $(18 \mathrm{kcal} / 100 \mathrm{~g}$ body weight/day; $\mathrm{n}=4)$; all administrations were performed daily, starting from day 3 of the experiment until the mice were sacrificed. 5-FU, 5-fluorouracil; OA, oral administration; TA, topical application.

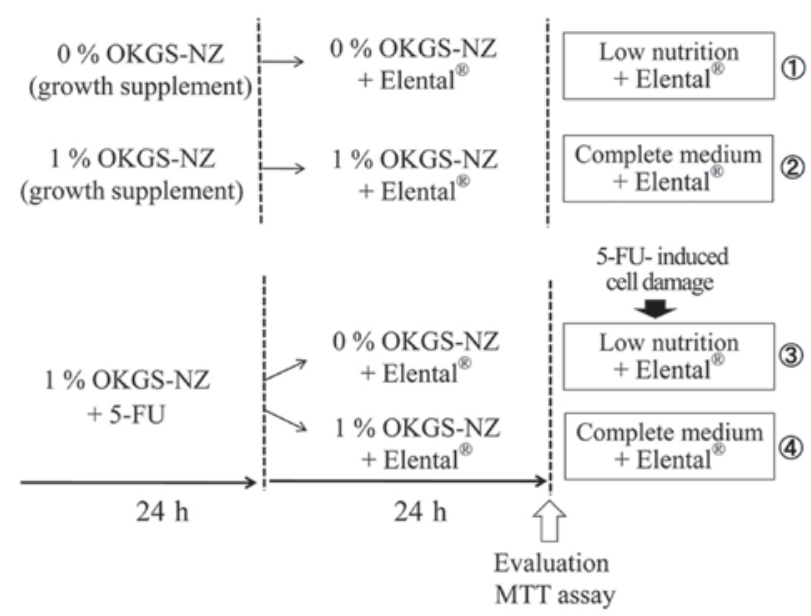

Figure 2. Treatment schedule for the MTT assay. After $24 \mathrm{~h}$ of cell seeding, cells were cultured in OKM-NZ medium containing 0 or $1 \%$ OKGS-NZ growth supplement, or $1 \%$ OKGS-NZ and $2 \mu \mathrm{g} / \mathrm{ml} 5$-FU. Then, both 5-FU treated or untreated cells were cultured in OKM-NZ medium containing 0 or $1 \%$ OKGS-NZ growth supplement and different concentrations of Elental ${ }^{\circledast}$. After $24 \mathrm{~h}$, the ability of the cells to proliferate was evaluated using an MTT assay. 5-FU, 5-fluorouracil; OKM-NZ, Oral Keratinocyte Medium (OKM)-New Zealand Origin BPE medium; OKGS-NZ, OKM-NZ complete medium consisting of OKM basal medium supplemented with $1 \%$ oral keratinocyte growth supplement-New Zealand Origin BPE. 
A

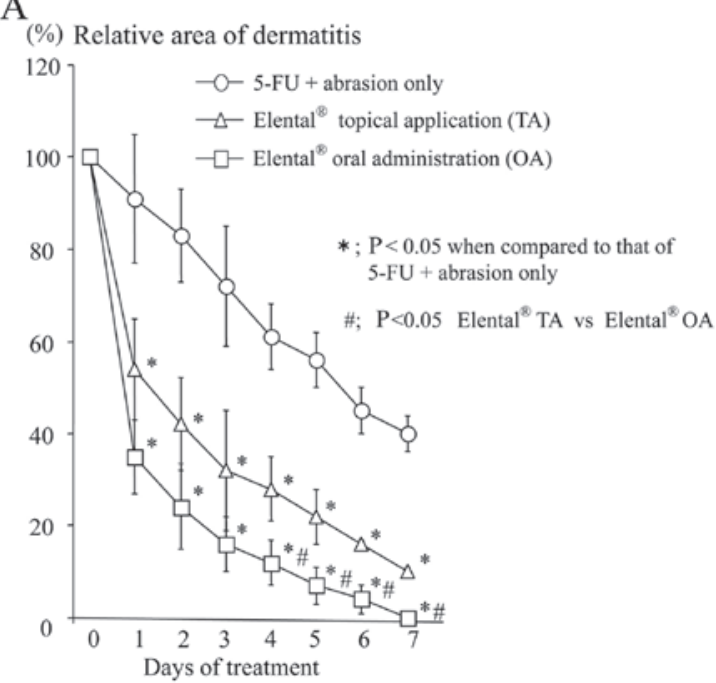

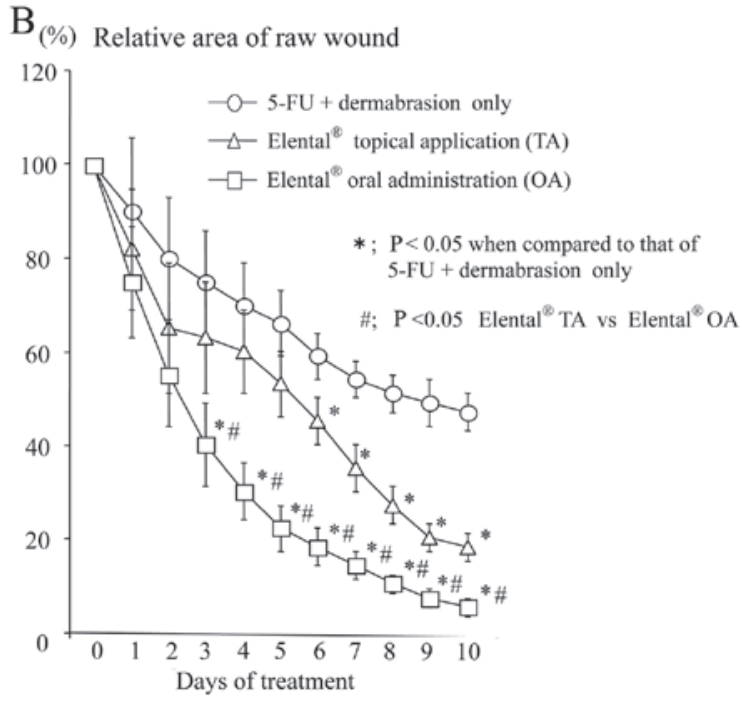

Figure 3. Effect of Elental ${ }^{\circledR}$ on 5-FU-induced dermatitis or raw wound areas of mouse dorsal skin. (A) The Elental ${ }^{\circledR}$ TA and OA groups exhibited better healing rates compared with the 5-FU + abrasion group (untreated control). Elental ${ }^{\circledR}$ OA healed dermatitis faster compared with Elental ${ }^{\circledR}$ TA. $(\mathrm{B})$ The Elental ${ }^{\circledR}$ TA and OA groups exhibited better healing rates compared with the 5-FU + dermabrasion group (untreated control), while Elental ${ }^{\circledR}$ OA healed wounded areas faster compared with Elental ${ }^{\circledR}$ TA. ${ }^{*} \mathrm{P}<0.05$ compared to 5 -FU + abrasion-treated animals or 5-FU + dermabrasion-treated animals. ${ }^{\#} \mathrm{P}<0.05$ compared between TA and OA in 5-FU + abrasion-treated animals or 5-FU + dermabrasion-treated animals. Data were analyzed using one-way analysis of variance and Tukey-Kramer multiple comparisons tests. 5-FU, 5-fluorouracil; OA, oral administration; TA, topical application.

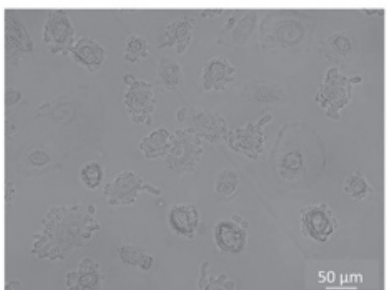

$0 \mu \mathrm{g} / \mathrm{ml}$

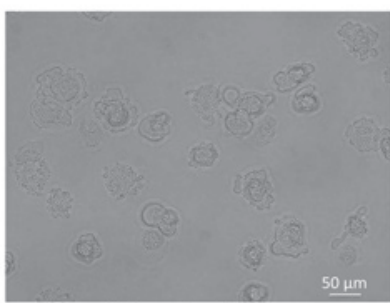

$10 \mu \mathrm{g} / \mathrm{ml}$

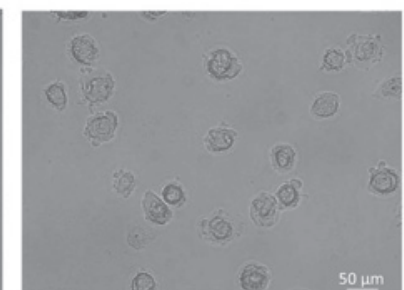

$0.1 \mu \mathrm{g} / \mathrm{ml}$

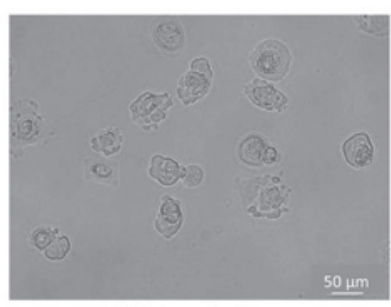

$100 \mu \mathrm{g} / \mathrm{ml}$

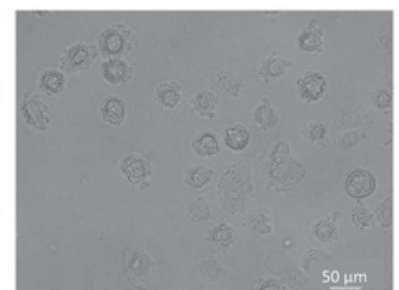

$1.0 \mu \mathrm{g} / \mathrm{ml}$

Elental $^{\circledR}(24 \mathrm{~h}$ treatment

Figure 4. Effect of Elental ${ }^{\circledR}$ on HOK morphology. The morphology of untreated or Elental ${ }^{\circledR}$ treated HOK cells were observed under an optical microscope (BX51; Olympus Corporation; magnification, x 100). Both untreated and Elental ${ }^{\circledR}$-treated HOKs showed similar morphology (scale bar, 50 im). HOKs, human oral keratinocytes.

\section{Results}

Effect of Elental ${ }^{\circledR}$ on dermatitis of mouse dorsal skin. To induce dermatitis on the dorsal skin in mice, 5-FU administration and mechanical trauma were used. Ulcerated skin tissue was observed after the second mechanical irritation (on day 3). As shown in Fig. 3A, the Elental ${ }^{\circledR}$ TA and OA groups exhibited better healing rates compared with the untreated control group (5-FU + abrasion). After 7 days of treatment (10th day of the experiment), the affected dorsal area had completely healed in the Elental ${ }^{\circledR}$ OA group, whereas the wound persisted in the Elental $^{\circledR}$ TA group.
Effect of Elental ${ }^{\circledR}$ on raw wound areas of mouse dorsal skin. The administration of 5-FU and dermabrasion with a surgical knife was used to induce raw wound areas on mouse dorsal skin. Compared with healing in the 5-FU + dermabrasion group (untreated control), the Elental ${ }^{\circledR}$ TA and OA groups exhibited better healing of the wounded areas (Fig. 3B). After 10 days of treatment (12th day of the experiment), Elental ${ }^{\circledR} \mathrm{OA}$ treatment had completely healed the raw wound area, whereas Elental ${ }^{\circledR}$ TA treatment had not.

Effect of Elental ${ }^{\circledR}$ on human oral keratinocyte cell morphology and proliferation. The morphology of HOKs cultured in 


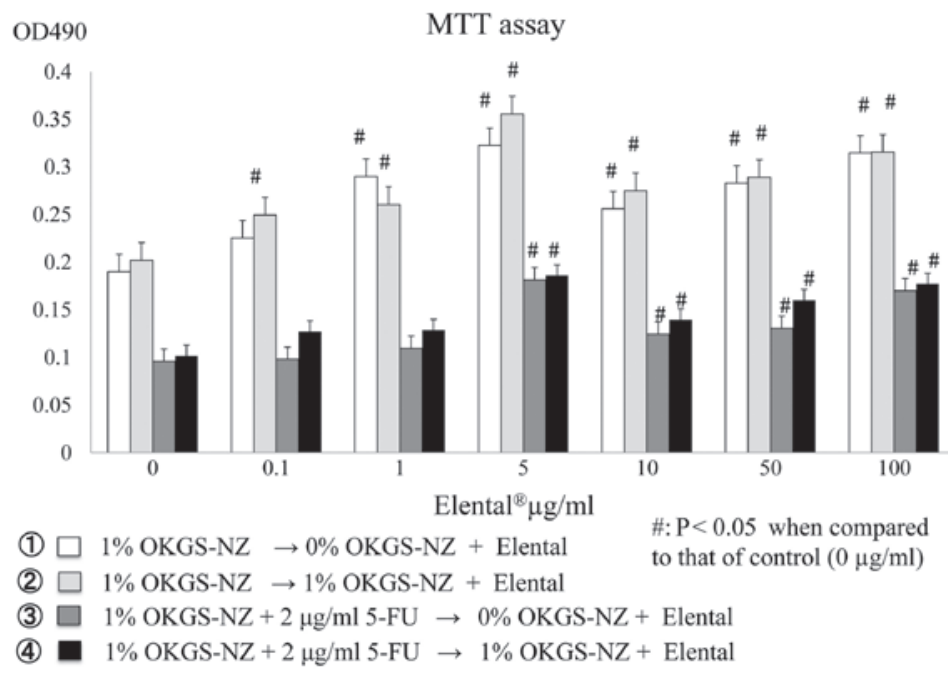

Figure 5. Proliferative activity of Elental ${ }^{\circledR}$-treated HOKs. Elenta ${ }^{\circledR}$ exerted a growth-promoting effect on all cells following 24 h of treatment, under both nutritionally poor conditions (medium with $0 \%$ OKGS-NZ growth supplement) and nutrient-rich or substantial conditions (medium with $1 \%$ OKGS-NZ). Elental ${ }^{\circledR}$ $(5-100 \mu \mathrm{g} / \mathrm{ml})$ exerted a proliferative effect on 5-FU $(2 \mu \mathrm{g} / \mathrm{ml})$-pretreated HOKs, even under nutritionally poor conditions, after $24 \mathrm{~h}$ of treatment. Error bars represent the standard deviation of the mean of three independent experiments. ${ }^{\prime \prime} \mathrm{P}<0.05$ compared to the control (one-way analysis of variance and Tukey-Kramer multiple comparisons tests). OD, optical density; HOKs, human oral keratinocytes; 5-FU, 5-fluorouracil; OKGS-NZ, Oral Keratinocyte Medium (OKM)-NZ complete medium consisting of OKM basal medium supplemented with $1 \%$ oral keratinocyte growth supplement-New Zealand Origin BPE.

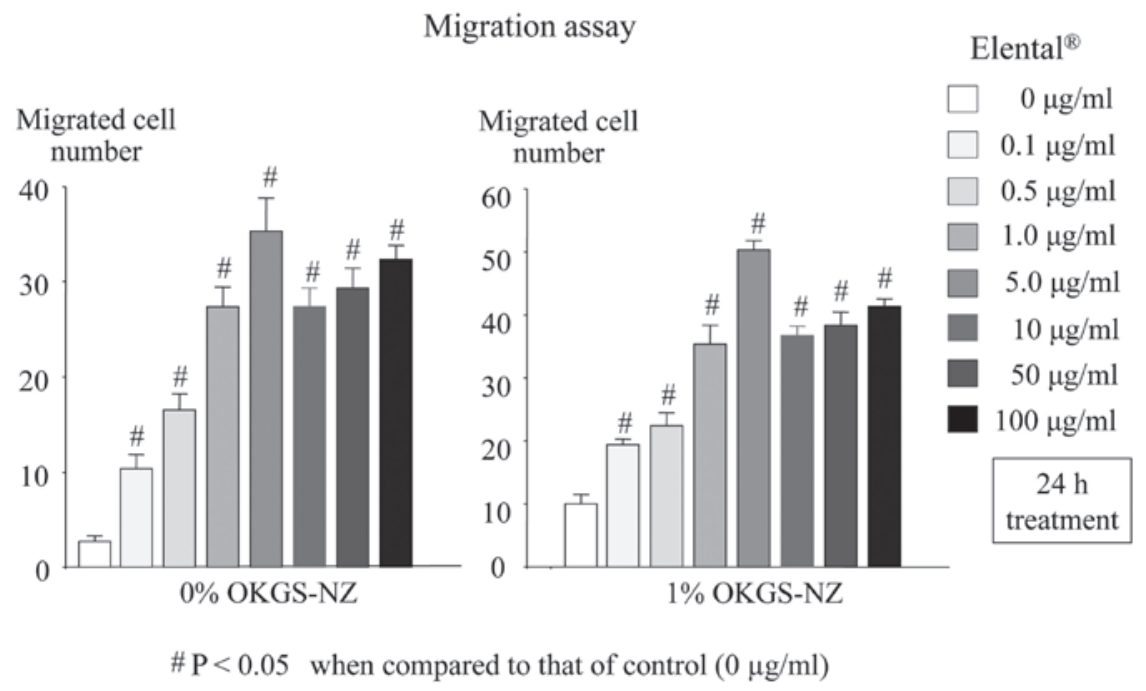

Figure 6. Migration activity of Elental ${ }^{\circledR}$-treated HOKs. The ability of Elenta ${ }^{\circledR}$-treated HOKs to migrate was significantly higher compared with that of untreated HOKs, under both nutritionally poor conditions (medium with $0 \%$ OKGS-NZ growth supplement) and nutrient-rich or substantial conditions (medium with $1 \%$ OKGS-NZ). Error bars represent the standard deviation of the mean of three independent observations. ${ }^{*} \mathrm{P}<0.05$ compared to the control (one-way analysis of variance and Tukey-Kramer multiple comparisons tests). HOKs, human oral keratinocytes; OKGS-NZ, Oral Keratinocyte Medium (OKM)-NZ complete medium consisting of OKM basal medium supplemented with $1 \%$ oral keratinocyte growth supplement-New Zealand Origin BPE.

OKM-NZ complete medium with or without Elental ${ }^{\circledR}$ was examined. No differences in morphology were detected between untreated and Elental ${ }^{\circledR}$-treated HOKs (Fig. 4). An MTT assay was used to measure the growth rate of the Elental ${ }^{\circledR}$-treated and untreated HOKs. As shown in Fig. 5, the growth rate of Elental ${ }^{\circledR}(0.1-100 \mu \mathrm{g} / \mathrm{ml})$-treated HOKs was higher compared with that of untreated HOKs after $24 \mathrm{~h}$ of culture, under both nutritionally poor conditions (medium with $0 \%$ OKGS-NZ growth supplement) and nutrient-rich or substantial conditions (medium for the optimal growth of cells, with $1 \%$ OKGS-NZ). Moreover, a higher concentration of Elental $^{\circledast}(5-100 \mu \mathrm{g} / \mathrm{ml})$ was able to stimulate the proliferation of 5-FU-pretreated $(2 \mu \mathrm{g} / \mathrm{ml})$ damaged HOKs, under both nutritionally poor and substantial conditions after $24 \mathrm{~h}$ of treatment. Among the concentrations tested, $5 \mu \mathrm{g} / \mathrm{ml}$ Elental ${ }^{\circledR}$ exerted the most prominent proliferative effect, both in healthy and 5-FU-damaged HOKs. Briefly, Elental ${ }^{\circledR}$ exerted a growth-promoting effect on all cells, even on damaged cells or cells cultured under nutritionally poor conditions.

Effect of Elental ${ }^{\oplus}$ on migration ability. The migration activity of Elental ${ }^{\circledR}$-treated HOKs was measured using a Boyden chamber. As shown in Fig. 6, Elental ${ }^{\circledR}$-treated HOKs exhibited a significantly higher migration ability compared with that of untreated HOKs, under both nutritionally poor conditions (medium with 0\% OKGS-NZ growth supplement), 
and nutrient-rich or substantial conditions (medium with $1 \%$ OKGS-NZ medium), while $5 \mu \mathrm{g} / \mathrm{ml}$ Elental ${ }^{\circledR}$ exerted a more noticeable effect on cell migration compared with other concentrations.

\section{Discussion}

Elental ${ }^{\circledR}$ is a good source of nitrogen and amino acids; it is an agent that is calorically dense, but with a low fat content (Table SI), which is suitable for enteral feeding, and its easily digestible nutrition formula does not require a fully functional digestive system $(1,3)$. It has been reported that early postoperative feeding with Elental ${ }^{\circledR}$ is beneficial in patients who have undergone surgery, as it provides a higher amount of nutrients that ultimately results in decreased weight loss (2-4). This ED is cost-effective, safe, and has been approved and covered by public insurance in Japan as an appropriate prescription treatment for malnutrition. Elental ${ }^{\circledR}$ has been reported to be effective in reducing the severity of chemotherapy-induced mucositis and dermatitis in patients with colorectal and esophageal cancer, as well as in acute Crohn's disease $(1,22-24)$. Elental ${ }^{\circledR}$ contains a large quantity of L-glutamine $(2.4 \mathrm{gm} / 100 \mathrm{~g})$, which helps in the treatment of cellular injuries, chemotherapy-induced cell toxicity and mucositis $(1,17,25-30)$. In our previous clinical study, Elental ${ }^{\circledR}$ was found to be effective for the treatment of chemotherapy-induced oral mucositis and dermatitis, without causing any adverse effects $(18,19)$.

In the present clinical study, Elenta ${ }^{\circledR}$ exerted strong healing effects against chemotherapy-induced oral mucositis when administered orally compared with its effects following nasal administration, which indicates that Elental ${ }^{\circledR}$ may not only act indirectly through gut immunity, but may also have a direct healing effect on wounded areas. However, there are currently no reports available on the direct effects of any ED, including Elental $^{\circledR}$. Therefore, it was investigated whether direct TA of Elental ${ }^{\circledR}$ could also accelerate recovery from oral mucositis or dermatitis in an animal model. The hamster cheek pouch model is one potential model for examining the effect of ED on oral mucositis. However, topically administering an ED inside a hamster's mouth on a daily basis is quite difficult; additionally, to assess any effects on a hamster's cheek pouch we would either have to use general anesthesia or sacrifice the animal. Therefore, numerous hamsters would be required for a single set of experiments. Instead, in the present study, a mouse model of dermatitis was used to assess the effect of Elental ${ }^{\circledR}$ on chemotherapy-induced dermatitis or raw wound areas. This mouse model of dermatitis may be considered as a suitable alternative model for oral mucositis. As expected, TA and OA of Elenta ${ }^{\circledR}$ both exerted better healing effects on dermatitis and raw wound areas compared with those observed in the untreated control (Fig. 3A and B), although the wounded areas healed more rapidly following Elental ${ }^{\circledR} \mathrm{OA}$ compared with Elental ${ }^{\circledR} \mathrm{TA}$. MTT and migration assays in vitro using HOKs were performed to further elucidate the effect of Elental ${ }^{\circledast}$ on cell growth and migration, which is important for the wound healing process. Although these in vitro assays cannot explain the differences between OA and TA, they may explain the mechanism of action of the possible 'direct effect' of Elental ${ }^{\circledR}$ that was observed in our mouse model. Elental ${ }^{\circledR}$ also exerted a growth-promoting effect on all cells, even damaged cells treated with 5-FU, as well as cells cultured under nutritionally poor conditions ( $0 \%$ OKGS-NZ medium) (Fig. 5). Furthermore, Elental ${ }^{\circledR}$ enhanced the migration ability of HOKs, irrespective of the nutritional conditions (Fig. 6). Therefore, it may be inferred that this cell growth-promoting property of Elental ${ }^{\circledR}$ may contribute to its direct healing effect on chemotherapy-induced dermatitis and mucositis. In the present study, no significant differences in body weight were observed between the groups with or without Elental ${ }^{\circledR}$ administration (data not shown). It was hypothesized that this was due to the fact that the mice had free access to food during these experiments. Whether Elental ${ }^{\circledR} \mathrm{TA}$ and OA exert synergistic effects against 5-FU-induced dermatitis or mucositis and in the healing of raw wound areas has yet to be investigated. We aim to evaluate the sequential or combined effects of Elental ${ }^{\circledR}$ TA and OA using in vivo dermatitis and mucositis models in the future.

In conclusion, the present study demonstrated that both oral and topical Elental ${ }^{\circledR}$ may act directly on chemotherapy-induced dermatitis and promote the healing of raw wounds in vivo; therefore, it is possible that oral or topical ED may also directly affect oral mucositis. This may explain why Elental ${ }^{\circledR}$ was able to reduce chemotherapy-induced oral mucositis more effectively when administered orally compared with when it was administered nasally, as observed in our previous clinical study.

\section{Acknowledgements}

Not applicable.

\section{Funding}

The present study was supported in part by a Grant-in-Aid from the Japanese Ministry of Education, Science and Culture (grant no. 15K11292).

\section{Availability of data and materials}

All data generated or analyzed during the present study are included in this published article.

\section{Authors' contributions}

KH and TT designed the study. TF performed the experiments. KH and TF analyzed the data, wrote and revised the manuscript. YM and KM revised the manuscript critically for important intellectual content and provided valuable suggestions during the study. All the authors have read and approved the final version of the manuscript and are fully responsible for its content.

\section{Ethics approval and consent to participate}

All procedures including animal handling and the experimental protocols were conducted according to the guidelines approved by the Ethical Committee for Animal Experimentation of Yamaguchi University (Yamaguchi, Japan).

\section{Patient consent for publication}

Not applicable. 


\section{Competing interests}

The authors declare that they have no competing interests.

\section{References}

1. Online EA Pharma Co., Ltd Products Information, Elental@. http://www.eapharma.co.jp/medi calexpert/product/elental/elental information.html, Webpage in Japanese. Accessed online: 25 July 2019.

2. Kawada J, Nishino M, Hata T, Tanizaki K, Ogino T, Hoshino H, Okano M, Nagai K, Kim Y, Okuyama M, et al: Analysis of patients who received nutritional support and the enhanced recovery after surgery (ERAS) protocol after esophagectomy. Gan To Kagaku Ryoho 45: 1524-1526, 2018 (In Japanese).

3. Ohkura Y, Haruta S, Tanaka T, Ueno M and Udagawa $\mathrm{H}$ : Effectiveness of postoperative elemental diet $\left(\right.$ Elental $\left.^{\circledR}\right)$ in elderly patients after gastrectomy. World J Surg Oncol 14: 268, 2016.

4. Imamura $\mathrm{H}$, Nishikawa $\mathrm{K}$, Kishi $\mathrm{K}$, Inoue $\mathrm{K}$, Matsuyama J, Akamaru Y, Kimura Y, Tamura S, Kawabata R, Kawada J, et al: Effects of an oral elemental nutritional supplement on post-gastrectomy body weight loss in gastric cancer patients: A randomized controlled clinical trial. Ann Surg Oncol 23: 2928-2935, 2016

5. Yamamoto T, Nakahigashi M, Umegae S, Kitagawa T and Matsumoto K: Impact of elemental diet on mucosal inflammation in patients with active Crohn's disease: Cytokine production and endoscopic and histological findings. Inflamm Bowel Dis 11: 580-588, 2005.

6. Hanai H, Iida T, Takeuchi K, Arai H, Arai O, Abe J, Tanaka T, Maruyama Y, Ikeya K, Sugimoto K, et al: Nutritional therapy versus 6-mercaptopurine as maintenance therapy in patients with Crohn's disease. Dig Liver Dis 44: 649-54, 2012.

7. Johtatsu T, Andoh A, Kurihara M, Iwakawa H, Tsujikawa T, Kashiwagi A, Fujiyama Y and Sasaki M: Serum concentrations of trace elements in patients with Crohn's disease receiving enteral nutrition. J Clin Biochem Nutr 4: 197-201, 2007.

8. Yamamoto T, Nakahigashi M, Saniabadi AR, Iwata T, Maruyama Y, Umegae S and Matsumoto K: Impacts of long-term enteral nutrition on clinical and endoscopic disease activities and mucosal cytokines during remission in patients with Crohn's disease: A prospective study. Inflamm Bowel Dis 13: 1493-1501, 2007.

9. Yamamoto T, Nakahigashi M, Umegae S, Kitagawa T and Matsumoto K: Impact of long-term enteral nutrition on clinical and endoscopic recurrence after resection for Crohn's disease: A prospective, non-randomized, parallel, controlled study. Aliment Pharmacol Ther 25: 67-72, 2007.

10. Kawada J, Nishino M, Hata T, Ogino T, Hoshino H, Okano M, Nagai K, Kim Y,Okuyama M and Tsujinaka T: Analysis of patients who received enteral nutrition in the course of chemotherapy. Gan To Kagaku Ryoho 44: 900-902, 2017 (In Japanese).

11. Kawaguchi Y, Lin JC, Kawashima Y, Maruno A, Ito H, Ogawa M and Mine T: Relationship between pain and plasma amino acid levels in chronic pancreatitis. JOP 16: 53-57, 2015.

12. Ogata Y, Ishibashi N, Yamaguchi K, Uchida S, Kamei H, Nakayama G, Hirakawa H, Tanigawa M and Akagi Y: Preventive effects of amino-acid-rich elemental diet Elental ${ }^{\circledR}$ on chemotherapy-induced oral mucositis in patients with colorectal cancer: A prospective pilot study. Support Care Cancer 24: 783-789, 2016.

13. Ogata Y, Takeuchi M, Ishibashi N, Kibe S, Takahashi K, Uchida S, Murakami N, Yahara T and Shirouzu K: Efficacy of Elental on prevention for chemotherapy-induced oral mucositis in colorectal cancer patients. Gan To Kagaku Ryoho 39: 583-587, 2012 (In Japanese).

14. Toyomasu Y, Mochiki E, Yanai M, Suzuki M, Yanoma T, Kimura A, Kogure N, Ogata K and Kuwano H: A prospective pilot study of an elemental nutritional supplement for prevention of oral mucositisduring S-1 adjuvant chemotherapy for gastric cancer. Surg Oncol 29: 97-101, 2019.
15. Ishikawa T, Yasuda T, Doi T, Okayama T, Sakamoto N, Gen Y, Dohi O, Yoshida N, Kamada K, Uchiyama K, et al: The amino acid-rich elemental diet Elental ${ }^{\circledR}$ preserves lean body mass during chemo- or chemoradiotherapy for esophageal cancer. Oncol Rep 36: 1093-1100, 2016.

16. Fukui T, Itoh Y, Orihara M, Yoshizawa K, Takeda H, Kawada S and Yoshioka T: Elental prevented and reduced oral mucositis during chemotherapy in patients esophageal cancer. Gan To Kagaku Ryoho 38: 2597-2601, 2011 (In Japanese).

17. Miki H, Tokuhara K, Oishi M, Tanaka Y, Nakatake R, Ueyama Y, Kaibori M, Nishizawa M, Okumura T and Kon M: Elental ${ }^{\circledR}$ amino acid component has protective effects on primary cultured hepatocytes and a rat model of acute liver injury. Nutr Res 42: 71-84, 2017

18. Harada K, Ferdous T, Horinaga D, Uchida K, Mano T, Mishima K, Park S, Hanazawa H, Takahashi S, Okita A, et al: Efficacy of elemental diet on prevention for chemoradiotherapy-induced oral mucositis in patients with oral squamous cell carcinoma. Support Care Cancer 24: 953-959, 2016.

19. Harada K, Minami H, Ferdous T, Kato Y, Umeda H, Horinaga D, Uchida K, Park SC, Hanazawa H, Takahashi S, et al: The Elental ${ }^{\circledR}$ elemental diet for chemoradiotherapy-induced oral mucositis: A prospective study in patients with oral squamous cell carcinoma. Mol Clin Oncol 10: 159-167, 2019.

20. Harada K, Ferdous T, Kobayashi H and Ueyama Y: Elemental diet accelerates the recovery from oral mucositis and dermatitis induced by 5-Fluorouracil through the induction of fibroblast growth factor 2. Integr Cancer Ther 17: 423-430, 2018.

21. Harada K, Ferdous T, Mizukami Y and Mishima K: Elemental diet inhibits pro-inflammatory cytokine production in keratinocytes through the suppression of NF- $\mathrm{KB}$ activation. Oncol Rep 40: 361-368, 2018.

22. Svanberg A, Ohrn K and Birgegard G: Oral cryotherapy reduces mucositis and improves nutrition- A randomised controlled trial. J Clin Nurs 19: 2146-2151, 2010.

23. Scully C, Epstein J and Sonis S: Oral mucositis: A challenging complication of radiotherapy, chemotherapy, and radiochemotherapy. Part 2: Diagnosis and management of mucositis. Head Neck 26: 77-84, 2004

24. Cowen D, Tardieu C, Schubert M, Peterson D, Resbeut M, Faucher $\mathrm{C}$ and Franquin JC: Low energy helium-neon laser in the prevention of oral mucositis in patients undergoing bone marrow transplant: Results of a double blind randomized trial. Int J Radiat Oncol Biol Phys 38: 697-703, 1997.

25. O’Dwyer ST, Scott T, Smith RJ and Wilmore DW: 5-fluorouracil toxicity on small intestinal mucosa but not white blood cells is decreased by glutamine. Clin Res 35: 367A, 1987.

26. Carneiro-Filho BA, Oriá RB, Wood Rea K, Brito GA, Fujii J, Obrig T, Lima AA and Guerrant RL: Alanyl-glutamine hastens morphologic recovery from 5-fluorouracil-induced mucositis in mice. Nutrition 20: 934-941, 2004.

27. Kandil HM, Argenzio RA, Chen W, Berschneider HM, Stiles AD, Westwick JK, Rippe RA, Brenner DA and Rhoads JM: L-glutamine and l-asparagine stimulate ODC activity and proliferation in a porcine jejunal enterocyte line. Am J Physiol 269: G591-G599, 1995.

28. Rhoads JM, Argenzio RA, Chen W, Rippe RA, Westwick JK, Cox AD, Berschneider HM and Brenner DA: L-glutamine stimulates intestinal cell proliferation and activates mitogen-activated protein kinases. Am J Physiol 272: G943-G953, 1997.

29. Hong RW, Rounds JD, Helton WS, Robinson MK and Wilmore DW: Glutamine preserves liver glutathione after lethal hepatic injury. Ann Surg 215: 114-119, 1992.

30. Denno R, Rounds JD, Faris R, Holejko LB and Wilmore DW: Glutamine-enriched total parenteral nutrition enhances plasma glutathione in the resting state. J Surg Res 61: 35-38, 1996. 